\title{
A Controversial Episode in the History of Artificial Cornea: The First Use of Poly(methyl methacrylate)
}

Traian Vasile Chirila and Geoffrey James Crawford

\section{Summary}

The introduction of the synthetic plastic poly(methyl methacrylate) as a material for artificial cornea (keratoprosthesis) is usually credited to William Stone, Jr. who allegedly performed the first experiments in 1947 and reported the results in 1953. As this plastic marked a revival in the development of artificial cornea, it is important to establish who was the first to use it and actually deserves the credit. This study demonstrates that at least three other ophthalmic surgeons (Wünsche in Germany, Franceschetti in Switzerland, and Györffy in Hungary) performed trials with keratoprostheses made from poly(methyl methacrylate) and published their results prior to Stone, Jr.

\section{Introduction}

At the front of the eye, the cornea is the first element of the ocular optical system. Its transparency and refractive power assure the production of sharp images of the outside world onto the retina, enabling us to see. Indeed, about $70 \%$ of the total dioptric power of the human eye is due to the interface between the cornea and the air. The cornea also performs protective functions against ultraviolet radiation, mechanical and chemical insults, and pathogenic invasion. Perhaps there is no better indication of the variety of functional requirements that the cornea must meet than its own complex structure, consisting of five discrete layers (epithelium, Bowman's layer, stroma, Descemet's membrane and endothelium), all within about $600 \mu \mathrm{m}$ of tissue.

Assoc. Professor Traian Vasile Chirila, Lions Eye Institute, 2 Verdun Street, Block A, Nedlands, Western Australia, 6009, Australia 
Under normal physiological conditions, the cornea is able to maintain "indefinitely" its own integrity and transparency. However, any of the complex processes governing the performance of the cornea can be disrupted by pathological conditions or trauma and the resulting disorders ${ }^{1-3}$ may cause partial or total loss of vision. Currently, the corneal disorders are the second most common cause of blindness in the world population, with only cataract prevailing.

Although modern ophthalmology provides effective treatment against many corneal disorders, for the permanently opacified corneas or for those so irregular that spectacles cannot restore a normal vision, only the transplantation of human donor corneal grafts offers hope of visual recovery. This operation, known as penetrating keratoplasty, is one of the most successful types of organ transplantation ${ }^{4}$. However, when the host cornea is extensively scarred, deeply vascularized, or in the presence of glaucoma, the success rate drops dramatically. Particularly, there is a disastrous outcome of penetrating keratoplasty when the patients are affected by specific conditions such as severe chemical burns, ocular pemphigoid, Stevens-Johnson syndrome, trachoma, severe dry eye syndrome, severe herpes zoster, metabolic opacities, and ectodermal dysplasia. Furthermore, graft rejection decreases the chance of success for repeated surgery. The only alternative for curing these patients is prosthokeratoplasty, a procedure in which the damaged cornea is replaced with an artificial cornea, known also as a keratoprosthesis.

Although it is impossible to duplicate the structural complexity of the natural cornea, almost two centuries of research and development work showed that it is possible to create an artificial substitute able to simulate the physical characteristics of the natural cornea and to perform some of its essential functions. A relatively modest number of publications ${ }^{5-13}$ dealt with the history of keratoprosthesis, covering the period from the first proposal of a glass disc in 1789 up to the polymeric core-and-skirt devices of the last decade.

1 Hogan M. J., Zimmerman L. E.: Ophthalmic Pathology. An Atlas and Textbook, Philadelphia, W. B. Saunders Co., 1962.

2 Greer C. H.: Ocular Pathology, 3rd edn, Oxford, Blackwell Scientific Publications, 1979.

3 Leibowitz H.M. (ed.): Corneal Disorders. Clinical Diagnosis and Management, Philadelphia, W. B. Saunders Co., 1984.

4 Casey T. A., Mayer D. J.: Corneal Grafting. Principles and Practice, Philadelphia, W. B. Saunders Co., 1984.

5 Forster A. E.: "A review of keratoplastic surgery and some experiments in keratoplasty", American Journal of Ophthalmology 6:366-375, 1923.

6 Day R.:"Artificial corneal implants", Transactions of the American Ophthalmological Society 55: 455-475, 1957.

7 Cardona H.: "Keratoprosthesis", American Journal of Ophthalmology 54: 284-294, 1962. 
In spite of past and recent efforts, no keratoprosthesis available today is fully successful in the long term. In some instances, the keratoprostheses were retained in patients and they maintained improved vision for longer than 10 years, but these cases are rather exceptions when compared to the much larger number of operations performed.

\section{Poly(methyl methacrylate) as material for keratoprostheses}

At the beginning of this century, the research and development work on keratoprosthesis has almost ceased as a result of consistent lack of long-term clinical success. Also, the first successful penetrating keratoplasty in a human patient ${ }^{14}$ diverted the surgeons' attention to the use of this procedure.

By the fifth decade of this century, the advantages and limitations of donor corneal grafts and the problems associated with the eye banking system were well defined, and the need for continuation of developmental work on artificial cornea became evident. The introduction of synthetic polymers (plastics) in the manufacture of keratoprostheses had an essential contribution to this change in the researchers' attitude. The modern era in the history of keratoprosthesis began with the use of poly(methyl methacrylate), henceforth PMMA, which was subsequently followed by the use of other synthetic polymers as materials for keratoprostheses. While the revolutionary impact of PMMA on the development of artificial cornea is unanimously recognized, the question of who was the first, and when, to introduce this polymer as a keratoprosthetic material is still debatable. The aim of our work is to refute a commonly accepted opinion on this matter, and to establish the historical truth.

8 Stone, Jr. W., Yasuda H., Refojo M. F.: "A 15 -year study of the plastic artificial cornea - basic principles", in The Cornea World Congress, ed. J. H. King and J.W. McTigue, Washington, DC, Butterworths, 1965, 654-671.

9 Giles C. L., Henderson J. W.: "Keratoprosthesis: current status", American Journal of the Medical Sciences 253: 239-242,1967.

10 Hruby K.: «Künstliche Hornhautimplantate (Keratoprothetik)», Wiener Klinische Wochenschrift 92: 227-233, 1980.

11 Barber J. C.: "Keratoprostheses: past and present", International Ophthalmology Clinics 28: 103-109, 1988.

12 Barron B. A.: "Prosthokeratoplasty", in The Cornea, ed. H. E. Kaufman, M. B. McDonald, B. A. Barron and S. R. Waltman, New York, Churchill Livingstone, 1988, 787-803.

13 Chirila T. V.: "Modern artificial corneas: the use of porous polymers", Trends in Polymer Science 2: 296-300, 1994.

14 Zirm E.: «Eine erfolgreiche totale Keratoplastik», Albrecht von Graefes Archiv für Ophthalmologie 64: 580-593, 1906. 
The story goes that during World War II, both Harold Ridley in England and William Stone, Jr. in the U.S.A. noticed that many airmen whose aeroplane canopies were shattered when hit by enemy fire had slivers of PMMA embedded in their eyes, and still the eyes did not seem particularly affected by the presence of a foreign material. This observation led the two ophthalmologists to use PMMA as prosthetic material, either for the replacement of cataractous crystalline intraocular lenses (Ridley), or as artificial corneas (Stone). It is beyond any doubt that Ridley was the first to start, in 1949, the implantation of PMMA intraocular lenses in human patients ${ }^{15-19}$, based on his direct observations as a military surgeon during the war and stimulated later by a naive comment of a student assisting him during a cataract extrac$\operatorname{tion}^{20}$. However, it is unlikely that Stone was indeed the first to use PMMA for keratoprostheses. This opinion, nevertheless, prevails in the majority of reviews on keratoprosthesis and in numerous introductions to articles on the topic, and only recently some doubts were expressed ${ }^{21}$.

In 1953 Stone and Herbert published a paper ${ }^{22}$ in which it was claimed that they implanted as early as 1947 keratoprostheses made of PMMA into rabbit eyes. The prostheses were made as buttons, and some of them had a peripheral tantalum meshwork or roughed edges. The devices, all implanted as full-thickness grafts, were rejected by the host cornea within 2 weeks. In 1949, a model with perforations along the peripheral zone and implanted intralamellarly, was much more successful, being maintained in the rabbit cornea for longer than 3 years ${ }^{23-25}$.

15 Ridley H.: "Intra-ocular acrylic lenses", Transactions of the Ophthalmological Society of the United Kingdom 71:617-621,1951.

16 Ridley H.: "Intra-ocular acrylic lenses after cataract extraction", The Lancet 1952(I): 118121.

17 Ridley H.: "Intra-ocular acrylic lenses. A recent development in the surgery of cataract", British Journal of Ophthalmology 36:113-122, 1952.

18 Chirila T. V., Constable I. J., Russo A. V., Linton R. G.: "Ridley intraocular lens revisited: chemical analysis of residuals in the original lens material",Journal of Cataract and Refractive Surgery 15: 283-288, 1989.

19 Apple D. J., Sims J.: "Harold Ridley and the invention of the intraocular lens", Survey of Ophthalmology 40: 279-292, 1996.

20 Apple (n. 19).

21 Chirila (n. 13).

22 Stone, Jr. W., Herbert E.: "Experimental study of plastic material as replacement for the cornea", American Journal of Ophthalmology 36(II): 168-173, 1953.

23 Stone, Jr. (n. 22).

24 Stone, Jr. W.: "Study of patency of openings in corneas anterior to interlamellar plastic artificial discs", American Journal of Ophthalmology 39(II): 185-196, 1955.

25 Stone, Jr. W.: "Alloplasty in surgery of the eye", The New England Journal of Medicine 258: $533-540,1958$. 
Our extensive literature search indicated that at the time of Stone's first publication ${ }^{26}$ three articles were already in existence ${ }^{27-29}$, and two more were published the same year $(1953)^{30,31}$, all reporting in vivo experiments with keratoprostheses made from PMMA. The first to report in print the use of PMMA in keratoprostheses was definitely Gottfried Wünsche in Germany ${ }^{32}$. There are some remarkable aspects of Wünsche's work, which was performed in rather inauspicious circumstances. He was on the battlefield in 1943 when, with no knowledge of any previously published work, he implanted into the rabbit cornea pieces of PMMA obtained from the canopy of a fallen aeroplane. To check the stability of the material, he treated samples of polymer with a concentrated solution of sodium chloride. Wünsche further tested the tissue tolerance to PMMA by implanting a piece under his own skin and observing its behaviour for 6 weeks. A keratoprosthesis was then manufactured in the garrison's field workshop and implanted as a full-thickness graft in 10 rabbits during 1944. In one animal, the device was maintained for almost 2 months without complications. Eventually, with the retreat of the defeated German army, the experiments were discontinued.

In his opening lecture ${ }^{33}$ at the 69 th annual congress of the Ophthalmological Society of the United Kingdom and affiliated societies (1949), the great Swiss ophthalmologist Franceschetti discussed briefly the partial success of his experiments with PMMA keratoprostheses in animals and in human patients, which began in 1947. In 1951 Györffy (Hungary) reported ${ }^{34}$ the implantation of a two-piece PMMA keratoprosthesis in a human patient with severe alkaline burns; although not clearly stated, this appears to be a delayed report of an operation performed in 1942 by Imre. The implant was rejected within 2 weeks.

In 1953 Sommer, in Germany, mentioned ${ }^{35}$ experiments with PMMA keratoprostheses in rabbits, performed in 1946. Finally, Macpherson and

26 Stone, Jr. (n. 22).

27 Wünsche G.: «Versuche zur totalen Keratoplastik und zur Cornea arteficialis», Ärztliche Forschung 1: 345-348, 1947.

28 Franceschetti A.: "Corneal grafting", Transactions of the Ophthalmological Society of the United Kingdom 69: 17-35, 1949.

29 Györffy I.: "Acrylic corneal implant in keratoplasty", American Journal of Ophthalmology 34: 757-758, 1951.

30 Sommer G.: «Neue Versuche zur Alloplastik der Kornea», Klinische Monatsblätter für Augenheilkunde und für Augenärztliche Fortbildung 122:545-554, 1953.

31 Macpherson D. G., Anderson J. M.: "Keratoplasty with acrylic implant", British Medical Journal 1953(I): 330.

32 Wünsche (n. 27).

33 Franceschetti (n. 28).

34 Györffy (n. 29).

35 Sommer (n. 30). 
Anderson, in England, reported the same year ${ }^{36}$ the intralamellar insertion of a PMMA prosthesis in the cornea of a human patient; the vision of the patient was restored significantly, and 2 years after the operation the status of the eye was still maintained ${ }^{37}$.

The only indication that Stone was aware of other previous work is his citation of Franceschetti's and Györffy's articles as references in the first publication $^{38}$. However, Stone's failure to admit their priority is obvious, and in his subsequent papers ${ }^{39,40,41}$ he systematically ignored any references to previous work on PMMA keratoprostheses done by others.

\section{Conclusion}

The situation described here is summarized in the following table.

\begin{tabular}{llll}
\hline $\begin{array}{l}\text { Author } \\
\text { (country) }\end{array}$ & $\begin{array}{l}\text { Year of published } \\
\text { report }\end{array}$ & $\begin{array}{l}\text { Year of experiments } \\
\text { (claimed) }\end{array}$ & $\begin{array}{l}\text { Subject of } \\
\text { experiments }\end{array}$ \\
\hline $\begin{array}{l}\text { Wünsche } \\
\text { (Germany) }\end{array}$ & 1947 & 1944 & animal \\
$\begin{array}{l}\text { Franceschetti } \\
\text { (Switzerland) }\end{array}$ & 1949 & 1947 & animal, human \\
$\begin{array}{l}\text { Györffy } \\
\text { (Hungary) }\end{array}$ & 1951 & 1942 & human \\
$\begin{array}{l}\text { Sommer } \\
\text { (Germany) }\end{array}$ & 1953 & 1946 & animal \\
$\begin{array}{l}\text { Stone, Jr. } \\
\text { (U.S.A.) }\end{array}$ & 1953 & 1947 & animal \\
$\begin{array}{l}\text { Macpherson and Anderson } \\
\text { (U.K.) }\end{array}$ & 1953 & 1952 & human \\
\hline
\end{tabular}

On this background, we believe there is no scientific or ethical justification to consider William Stone, Jr. as the first surgeon who proposed and experimented artificial corneas manufactured from poly(methyl methacrylate). Using any criteria, either the date of published reports or the claimed date of experiments, Stone's work can be ranked at the best as the fourth in chronological order.

36 Macpherson (n. 31).

37 Macpherson D. G., Anderson J. M.: "Keratoplasty with acrylic implant", British Medical Journal 1954(I): 819 .

38 Stone, Jr. (n. 22).

39 Stone, Jr. (n. 24).

40 Stone, Jr. (n. 25)

41 Stone, Jr. (n. 8). 


\section{Acknowledgements}

This work was supported in part by the National Health and Medical Research Council of Australia (Grant \# 910167). The authors express their gratitude to Dr. Hilda Bodnaras for translating the sources from German language. 